\title{
Ionic Currents of Cultured Olfactory Receptor Neurons from Antennae of Male Manduca sexta
}

\author{
Frank Zufall, ${ }^{1}$ Monika Stengl, ${ }^{2}$ Christian Franke, ${ }^{1}$ John G. Hildebrand, ${ }^{2}$ and Hanns Hatt ${ }^{1}$ \\ 'Physiologisches Institut der Technischen Universität München, 8000 München 40, Germany, and ${ }^{2}$ Arizona Research \\ Laboratories, Division of Neurobiology, University of Arizona, Tucson, Arizona 85721
}

\begin{abstract}
Whole-cell and single-channel voltage-clamp techniques were used to identify and characterize the ionic currents of insect olfactory receptor neurons (ORNs) in vitro. The cells were isolated from the antennae of male Manduca sexta pupae at stages 3-5 of adult development and maintained in primary cell culture. After 2-3 weeks in vitro, the presumptive ORNs had resting potentials of $-62 \pm 12 \mathrm{mV}(n=$ 18) and expressed at least 1 type of $\mathrm{Na}^{+}$channel and at least 3 types of $\mathrm{K}^{+}$channels. $\mathrm{Na}^{+}$currents, recorded in the whole-cell mode, were reversibly blocked by $0.1 \mu \mathrm{M}$ tetrodotoxin. The predominant type of $\mathrm{K}^{+}$channel observed was a voltage-activated $\mathrm{K}^{+}$channel $(\gamma=30 \mathrm{pS})$ with characteristics similar to those of the delayed rectifier. The activity of the 30-pS K+ channel could be inhibited by the application of nucleotides to the cytoplasmic face of inside-out patches of membrane. The nucleotides had relative potencies as follows: ATP > CGMP > CAMP, with an inhibition constant for ATP of $K_{l}=0.18 \mathrm{~mm}$. Raising the intracellular $\mathrm{Ca}^{2+}$ concentration from 0.1 to $5 \mu \mathrm{m}$ induced the opening of a $\mathrm{Ca}^{2}$ activated $\mathrm{K}^{+}$channel $(\gamma=66 \mathrm{pS}$ at $0 \mathrm{mV})$ that had a low voltage sensitivity. A third, transient type of $K^{+}$channel $(\gamma$ $=12-18 \mathrm{pS}$ ) could be activated by depolarizing voltage steps from very negative resting potentials. Properties of this channel were similar to those of the "A-channel." These results support the conclusion that $M$. sexta ORNs differentiate in vitro and provide the basis for studying primary mechanisms of olfactory transduction.
\end{abstract}

In the male sphinx moth Manduca sexta, the antennal flagellum carries 40,000-70,000 specialized, sexually dimorphic sensory organules, the sensilla trichodea, which respond specifically to components of the sex-pheromone blend of conspecific females. Each of these sensilla consists of a hollow cuticular hair (ca. $400-500 \mu \mathrm{m}$ long) innervated by the dendrites of 2 bipolar olfactory receptor neurons (ORNs) and 4 auxiliary cells (thecogen, tormogen, and trichogen cells) associated with the sen-

\footnotetext{
Received July 17, 1990; revised Oct. 19, 1990; accepted Oct. 24, 1990.

We thank Deborah Sakiestewa and Dr. Helmut Wieczorek for providing insects, Drs. Jon Hayashi and Lynne Oland for giving us conditioned medium, Drs. Jürgen Daut and Joseph Dudel for valuable comments on the manuscript, Drs. Sue Kinnamon and Brian Waldrop for masterful advice and encouragement, and Drs. Karl-Ernst Kaissling, Richard B. Levine, Helmut Wieczorek, and Gunde Ziegelberger for helpful discussions. We also thank Dr. H.-J. Bestmann for providing bombykal and D. Beyer, W. Zeitz, and Birgit Preibisch for expert technical assistance. This research was supported in part by NIH Grant AI-23253 to J.G.H.

Correspondence should be addressed to Dr. John G. Hildebrand, ARL Division of Neurobiology, 611 Gould-Simpson Building, University of Arizona, Tucson, AZ 85721 .

Copyright C 1991 Society for Neuroscience $0270-6474 / 91 / 110956-10 \$ 03.00 / 0$
}

sory neurons (Sanes and Hildebrand 1976a,b; Kaissling et al, 1989; Keil, 1989; Lee and Strausfeld, 1990). In the lumen of the hair, the outer dendritic segments are bathed by a high- $\mathrm{K}^{+}$ "receptor lymph" (ca. $200 \mathrm{mM} \mathrm{K}^{+}$; A. Dörge and H. Hatt, unpublished observations).

The electrical properties of insect ORNs are poorly understood. From extracellular recordings, it is known that pheromone components elicit a graded depolarizing receptor potential, which leads to the generation of action potentials (for review, see Kaissling, 1986, 1987). Until now, however, intracellular recordings have not been obtained from insect ORNs owing to the small size of these receptor cells and the obstacle posed by the closely apposed supporting cells.

A necessary prerequisite for understanding the events leading from the detection of odorant molecules to the transmission of electrical impulses to the brain is a clear description of membrane properties and the underlying ionic currents of ORNs. For this purpose, the patch-clamp technique (Hamill et al., 1981) is especially suitable, particularly for small cells. This technique requires clean (and preferably isolated) cells, however. We therefore developed procedures for long-term primary culture of cells dissociated from antennal flagella of male $M$. sexta pupae (Stengl and Hildebrand, 1990). In these cultures, the male-specific ORNs can be identified by the use of 2 specific monoclonal antibodies (Hishinuma et al., 1988a,b): olfactory-specific antibody (OSA) and male olfactory-specific antibody (MOSA). Immunocytochemical studies in vitro revealed that the male-specific (OSA- and MOSA-immunoreactive) ORNs belong to a certain morphological type of cultured antennal cells (Stengl and Hildebrand, 1990). The presumptive ORNs were distinguished from other antennal receptor neurons by the size of their somata (ca. $5 \mu \mathrm{m}$ ) and by their typically bipolar, fine neurites.

In this paper, we present the results of patch-clamp studies of the physiological properties of $M$. sexta ORNs after 2-3 weeks in vitro. Preliminary reports of some of this work have been presented elsewhere (Stengl et al., 1989; Zufall et al., 1989).

\section{Materials and Methods}

Animals. Manduca sexta (Lepidoptera:Sphingidae) were rcared from eggs on an artificial diet (modified from Bell and Joachim, 1976) on a long-day photoperiod regimen $\left(17 \mathrm{hr}\right.$ light $/ 7 \mathrm{hr}$ dark) at $26^{\circ} \mathrm{C}$ and $50-$ $60 \%$ relative humidity. Pupae were staged as previously described (Sanes and Hildebrand, 1976a; Tolbert et al., 1983). They were usually selected for dissection between 2:00 and 5:00 Arbitrary Zeitgeber time (AZT; lights-on at 00:00 AZT) and anesthetized by chilling on ice for 10-15 min before dissection to isolate the antennal flagellum.

Cell cultures. Unless otherwise specified, all culture media were purchased from GIBCO (Grand Island, NY), and all chemicals and biochemicals, from Sigma Chemical Co. (St. Louis, MO). 
Antennal flagella from $M$. sexta pupae (late stage 2 to early stage 3 of adult development) were disrupted by a combination of mechanical and enzymatic treatments in Hanks' balanced salt solution containing papain $(1 \mathrm{mg} / \mathrm{ml})$. After $20-150 \mathrm{~min}$ in this solution, the dispersed cells were collected and washed by centrifugation twice for about $8 \mathrm{~min}$ at $1000 \mathrm{rpm}$ in $\mathrm{L} 15$ medium supplemented with $5 \%$ fetal bovine serum (LFBS). The pellet containing dispersed antennal cells was resuspended in L15 medium, and aliquots were plated on uncoated Falcon plastic dishes, Nunc plastic dishes, or coverslips coated with concanavalin A in LFBS ( $374 \mathrm{mOsm}$ ) supplemented with $\beta$-ecdysone or conditioned medium (supernatant fluid from primary cultures of non-neural $M$. sexta cells, generously provided by Drs. J. Hayashi and L. Oland, or extracellular fluid from antennae; Stengl and Hildebrand, 1990). The cultures were maintained for $2-3$ weeks at about $30^{\circ} \mathrm{C}$ in an incubator at high humidity.

Patch-clamp technique and data analysis. Patch-clamp recording closely followed the methods described by Hamill et al. (1981). Patch pipettes were made from borosilicate glass capillaries (World Precision Instruments, GC 150 T10) using a 2-stage electrode puller (DMZ, Zeitz Instruments, Augsburg, FRG). The pipettes were coated with Sylgard (Dow Corning, Midland, MI) and then fire polished. The tip resistance was 4-6 M $\Omega$ when the electrodes were filled with physiological saline solution.

The neurons were viewed at $320 \times$ magnitication with a Zeiss Axiovert 10 inverted microscope equipped with phase-contrast optics. High-resistance seals $(10-20 \mathrm{G} \Omega)$ between the electrode and the cell surface were formed by applying gentle suction to the lumen of the pipette that had contacted the cell surface. Whole-cell recordings were obtained by applying further suction to the pipette (pipette and holder capacitance had been compensated prior to patch rupture). Access to the cell's interior was signaled by a large increase in noise and capacitative current in response to applied voltage steps. Both membrane capacitance and the series resistance of the pipette were compensated. Leakage currents were not subtracted in the whole-cell recordings.

Whole-cell and single-channel currents were measured at room temperature with an EPC-7 amplifier (List Electronic, Darmstadt, FRG). The signals were recorded on videotape with a modified Sony PCM501-ES videorecorder. Single-channel currents were then low-pass filtered at $2-5 \mathrm{kHz}$ with an 8 -pole Bessel filter and digitally sampled at $25 \mathrm{kHz}$ using a Hewlett-Packard P 9802 computer equipped with a Hewlett-Packard multiprogrammer II interface. The event-detection program described by Dudel and Franke (1987) was used to evaluate single-channel currents. The open probability $P$ of single-channel currents was calculated according to Equation 1 , where $N$ is the number of channels in the patch, $i$ is the single-channel amplitude, and $I$ is the mean current:

$$
P=I /(N \cdot i)
$$

Mean current was calculated by integrating current flow during channel openings and dividing the integral by the total time of the sample. If single-channel currents were activated by voltage stcps, the program described by Franke and Hatt (1990) was used to subtract leak currents and capacity transients and to average the records. Under all recording conditions, the current and potential across the membrane under study are described according to the usual sign convention; that is, the external side of the membrane is taken as reference, and outward currents are positive and are displayed as upward deflections.

Solutions. Cells were continuously superfused with saline containing (in mM) $156 \mathrm{NaCl}, 4 \mathrm{KCl}, 6 \mathrm{CaCl}_{2}, 5$ glucose, and 10 HEPES (adjusted to $\mathrm{pH} 7.1$ with $\mathrm{NaOH}$ ). In one experiment, $\mathrm{Na}^{+}$in this solution was replaced by choline. The "intracellular" pipette-filling solution for wholecell and outside-out recordings contained (in $\mathrm{mM}$ ) $150 \mathrm{KCl}, 5 \mathrm{NaCl}, 2$ $\mathrm{MgCl}_{2}, 0.1$ EGTA ( $\mathrm{pCa} \geq 7$ ), and 10 HEPES (adjusted to $\mathrm{pH} 7.2$ with $\mathrm{KOH}$ ). The final $\mathrm{K}^{+}$concentration was $154 \mathrm{mM}$. For desired levels of intracellular free $\mathrm{Ca}^{2+}$, EGT $\Lambda$ was omitted from this solution. This resulted in a basal concentration of $5 \mu \mathrm{M}$ free $\mathrm{Ca}^{2+}$ (as indicated by flame spectrophotometry). For higher free $\mathrm{Ca}^{2+}$ levels, $\mathrm{CaCl}_{2}$ was added as necessary. In some experiments, all $\mathrm{K}^{\prime}$ in the intracellular solution was replaced by $\mathrm{Cs}^{+}$.

Drug-application system. For the whole-cell recordings, drugs were delivered to individual cells from a "puffer" pipette with a tip opening of about $10 \mu \mathrm{m}$, driven by a Picospritzer (General Valve Corp., Fairfield, NJ). In the excised-patch experiments, the electrode with the patch at its tip was moved through the air from the culture dish to an isolated recording chamber by means of the "sleeve" technique of Quartararo
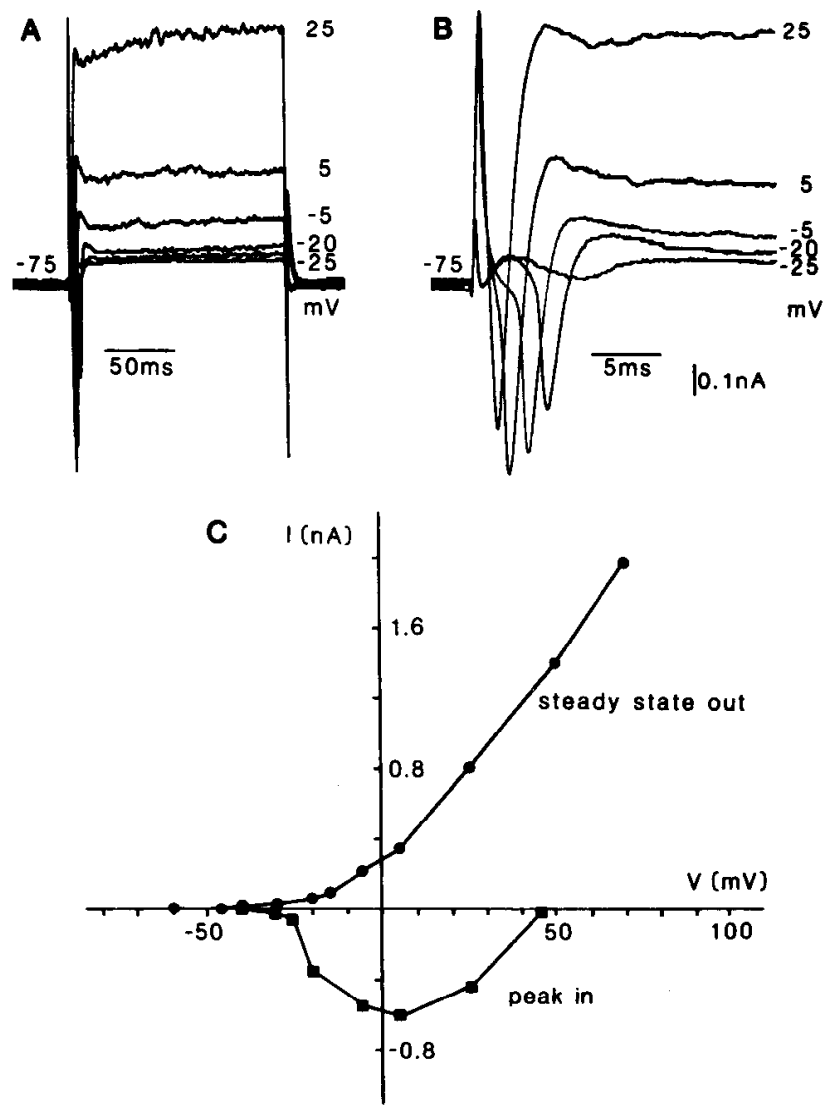

Figure 1. Time course of whole-cell currents in response to depolarizing voltage steps from a holding potential of $-75 \mathrm{mV}$ to the values indicated at the right of the traces. $A$ and $B$ are from the same recording at 2 different time scales. $C$, Peak of the transient inward currents (squares) following an initial capacitative transient and steady-state outward currents (circles) as a function of command pulse voltage. Data are from the recording shown in $A$ and $B$.

and Barry (1987). A polythene sleeve placed on the pipette shaft could be slipped down over the tip, trapping a drop of solution by surface tension and thus keeping the membrane patch covered with saline solution during transfer. Fresh saline solution flowed continually (by gravity feed) through the recording chamber. The chamber was equipped with a "liquid-filament" switch (Franke et al., 1987) for very fast changes of the solution contacting the membrane patch under study (within 200 $\mu \mathrm{sec}$ ). A "liquid filament" is ejected into the superfusing solution from a small tube that can be shifted by a piezoelectric device so that the liquid filament intersects the excised membrane patch at the tip of a patch electrode.

\section{Results}

\section{Whole-cell recordings}

All data were obtained from $M$. sexta ORNs that had been in primary cell culture for at least $14 \mathrm{~d}$. The development of ionic currents will be described elsewhere.

In whole-cell recordings, ORNs had a resting potential of $V_{0}$ $=-62 \pm 12 \mathrm{mV}$ (mean $\pm \mathrm{SD} ; n=18$ ). The input resistance was determined from the slope of the current-voltage $(I-V)$ relationship between -70 and $-150 \mathrm{mV}$, where no gated currents were present. The mean input resistance $( \pm \mathrm{SD})$ was 0.7 $\pm 0.2 \mathrm{G} \Omega(n=15)$, and the membrane time constant was typically about $25 \mathrm{msec}$. From these values, a membrane capacitance of about $35 \mathrm{pF}$ could be calculated. Using the membrane time constant of $25 \mathrm{msec}$, we calculated a specific membrane resistance of $25 \mathrm{~K} \Omega \cdot \mathrm{cm}^{2}$. 

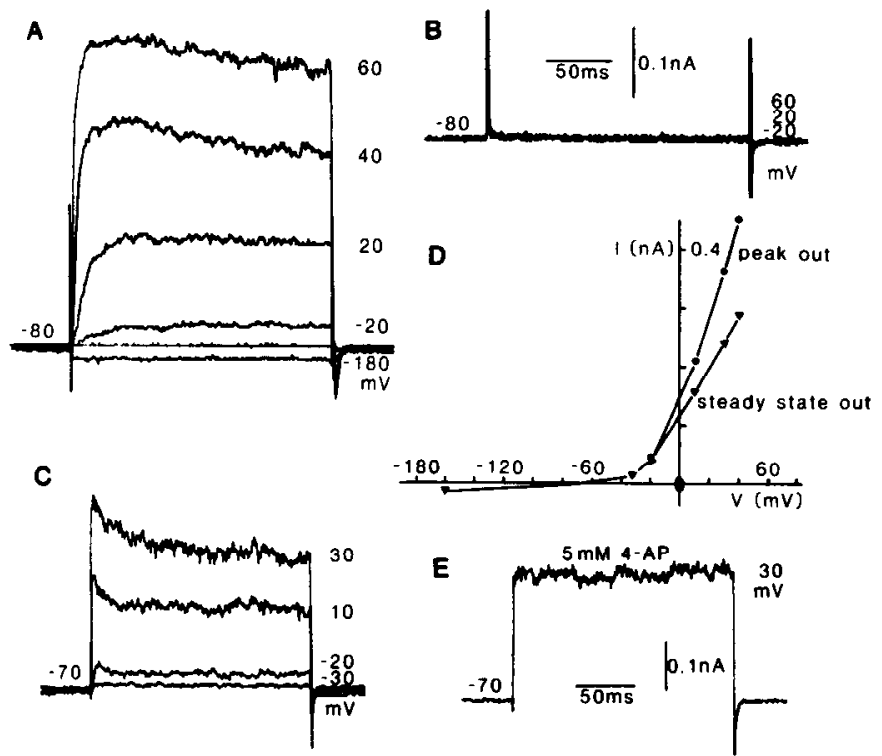

Figure 2. Outward currents. Inward currents were blocked with 0.1 $\mu \mathrm{M}$ TTX present in the extracellular solution. $A$, Outward currents in response to depolarizing voltage steps from $-80 \mathrm{mV}$. In this cell, only a slowly activating, noninactivating outward current component was present. With higher depolarization to $+40 \mathrm{mV}$ or more, some inactivation developed. Hyperpolarization to $-180 \mathrm{mV}$ did not induce an active current component (same scale as in $B$ ). $B$, Whole-cell recording from another cell using an "intracellular" solution in the pipette, which contained $\mathrm{Cs}^{+}$as the main intracellular cation instead of $\mathrm{K}^{+}$. In this case, no detectable gated currents could be recorded. $C$, Voltage-activated outward currents from a cell that expressed both a sustained outward current and a rapidly activated and then inactivating outward current (same scale as in $E$ ). $D$, Current-voltage relation of the 2 components of outward current shown in $C$. $E$, The transient component of the outward current could be blocked by the application of $5 \mathrm{~mm}$ 4-AP from a "puffer" pipette onto the cell (same cell as in $C$ ).

Figure 1, $A$ and $B$, shows whole-cell currents of ORNs in response to depolarizing voltage steps from a holding potential of $-75 \mathrm{mV}$, plotted on 2 different time scales. A fast, transient inward current was followed by a more slowly developing outward current. The inward current appeared at $-30 \mathrm{mV}$ and became larger, faster, and shorter with increasing depolarization. It reached a peak of $-0.6 \mathrm{nA}$ at $5 \mathrm{mV}$ within $3 \mathrm{msec}$. With further depolarization, the current amplitude decreased. The outward current apparently consisted of at least 2 components: a small inactivating component and a noninactivating one. The $I-V$ curves for the peak inward current and the steady-state outward current are shown in Figure $1 C$.

In the recording of Figure $1 B$, a pronounced delay of the inward current with smaller depolarizations is indicative of currents generated in unclamped regions of the cell. Because incomplete rupture of the membrane patch may decrease the efficiency of the clamp, we took great care to ensure good access to the interior of the cell. In some of our recordings, however, trains of oscillating fast inward currents passed the soma membrane during small depolarizations, suggesting that the site of generation of action potentials was not adequately space clamped during the voltage steps. Thus, no detailed analysis of activation and inactivation kinetics of the inward current could be performed.

The rapidly inactivating inward current was reversibly blocked by $0.1 \mu \mathrm{M}$ tetrodotoxin (TTX). This current component was
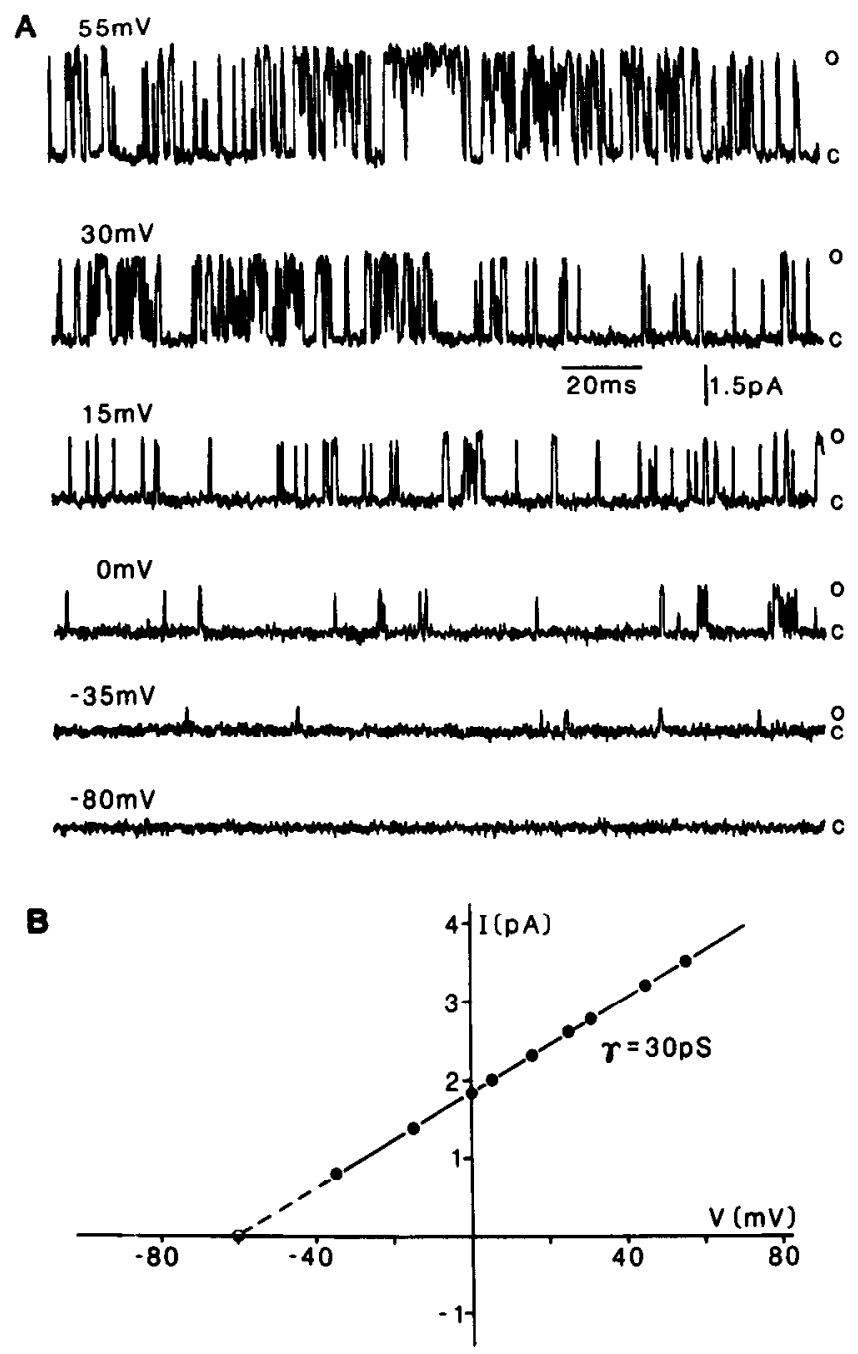

Figure 3. Activity of the delayed-rectifier $\mathrm{K}^{+}$channel recorded in the cell-attached mode with extracellular solution in the pipette. $A$. Singlechannel recordings of responses to stationary depolarization to the indicated values. Channel openings ( $o$, outward currents) corresponded to upward deflections from the closed state $(c)$. Upon depolarization, openings became larger and more frequent. $B$. Evaluation of single-channel current amplitudes as a function of membrane potential. The slope of the curve gave a single-channel conductance of $\gamma=30 \mathrm{pS}$. Linear extrapolation of $I-V$ curve gave a 0 -current potential of $-60 \mathrm{mV}$. Bandwidth, 0-3 kHz.

complctely abolished when choline was substituted for $\mathrm{Na}^{+}$in the extracellular solution. From these results, we conclude that the fast inward current is an $\mathrm{Na}^{+}$current.

\section{Potassium currents}

An analysis of outward currents is shown in Figure 2. The $\mathrm{Na}^{+}$ currents were blocked by addition of $0.1 \mu \mathrm{M}$ TTX to the extracellular solution. A sustained, voltage-dependent outward current remained (Fig. 2A). This current was elicited by voltage steps from a holding potential of $-80 \mathrm{mV}$ to $-30 \mathrm{mV}$ or more. The current activated slowly and typically reached $0.4 \mathrm{nA}$ at 60 $\mathrm{mV}$. Beyond $30 \mathrm{mV}$, some inactivation developed. External application of $5 \mathrm{~mm}$ 4-aminopyridine (4-AP) did not significantly reduce the sustained outward current, but external application of $20 \mathrm{~mm}$ tetraethylammonium (TEA) significantly reduced it. In 5 cells, outward currents were abolished if intra- 

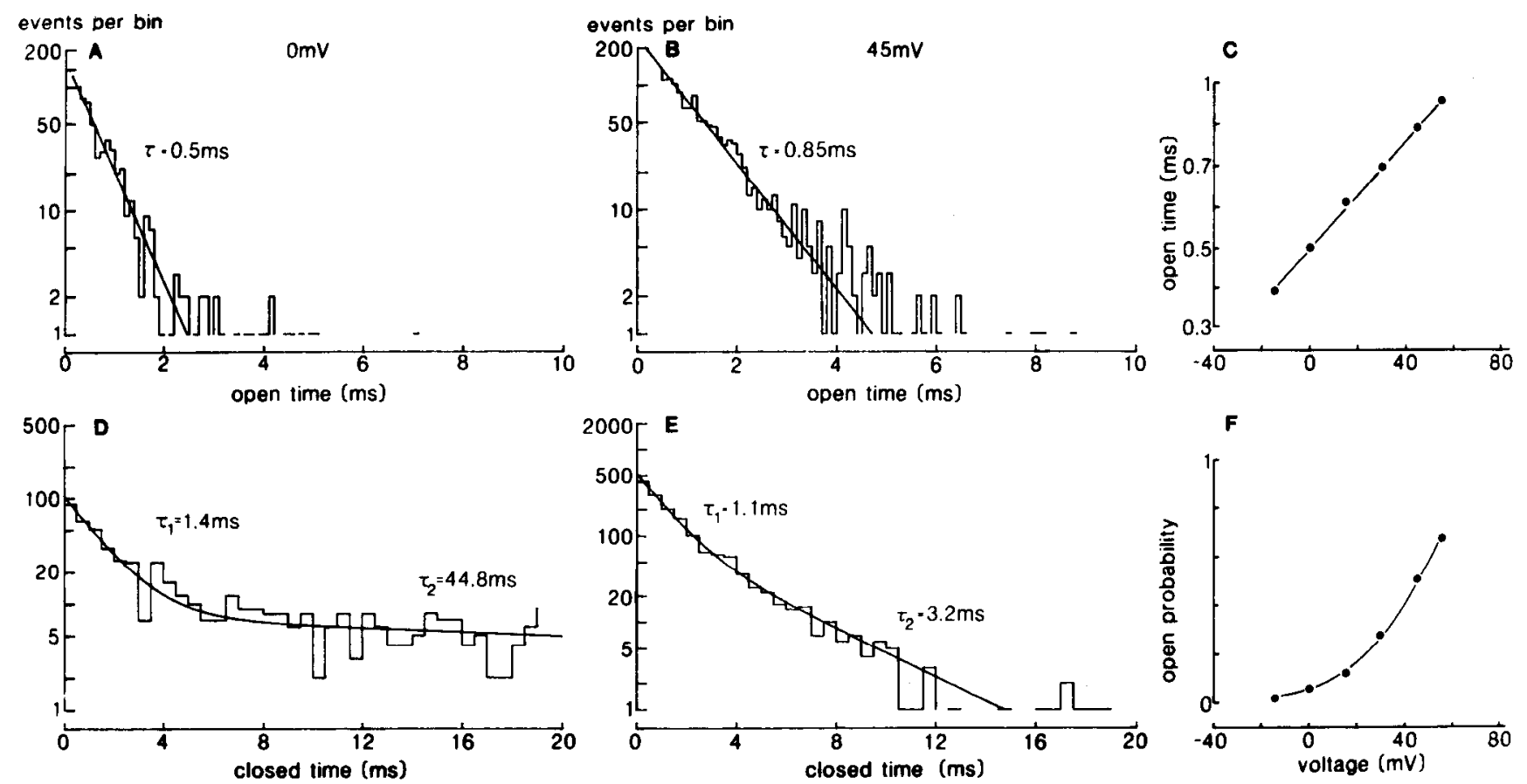

Figure 4. Evaluations of the recordings shown in Figure 3. Distributions of open times $(A, B)$ and closed times $(D, E)$ at 2 different potentials $(0$ $\mathrm{mV}$ and $+45 \mathrm{mV})$. Bin width, $0.1 \mathrm{msec}(A, B)$ and $0.4 \mathrm{msec}(D, E)$. Open-time distributions could be fit by a single exponential with time constants of $0.5 \mathrm{msec}$ at $0 \mathrm{mV}$ and $0.85 \mathrm{msec}$ at $+45 \mathrm{mV}$, respectively. Closed-time distributions were fit by the sum of 2 exponentials with time constants of 1.4 and $44.8 \mathrm{msec}$ or 1.1 and $3.2 \mathrm{msec}$, respectively. $C$, Linear correlation between open time and membrane potential. Slope of the curve connecting the values is $0.067 \mathrm{msec} / 10 \mathrm{mV}$. $F$, The open probability of the delayed-rectifier $\mathrm{K}^{+}$channel is exponentially correlated to the membrane potential. For definition of open probability, see text.

cellular $\mathrm{K}^{+}$was replaced by $\mathrm{Cs}^{+}$(Fig. $2 B$ ). The $I-V$ relationship of the sustained outward current showed outward rectification (Figs. 1C, 2D). These results indicate that the main outward current of $M$. sexta ORNs is a $\mathrm{K}^{+}$current with characteristics similar to those of the delayed (outward) rectifier $\left(I_{\mathrm{K}}\right.$; for review, see Hille, 1984). No indication of the existence of an anomalously (inwardly) rectifying $\mathrm{K}^{+}$current has been found in these cells so far.

In most of the ORNs, another outward current component could be seen in addition to the sustained current (Fig. 2C). This transient current was elicited at the beginning of a voltage change. The ratio of peak to steady-state currents varied between cells. The time constant of inactivation was not determined because the time course of the total current probably reflected the sum of the inactivation of the transient current and the activation of the delayed-rectifier current. The transient component of the current was absent when the cell was depolarized from a holding potential more positive than $-50 \mathrm{mV}$. Figure $2 D$ shows the $I-V$ relationship of the outward current of Figure $2 C$ as taken from the peak values and from the steady-state values of the current traces. The transient current could be blocked by the external application of $5 \mathrm{~mm} 4-\mathrm{AP}$, as shown in Figure $2 E$. Thus, the inactivating outward current component exhibited some of the characteristics of the "A current" $\left(I_{A}\right)$ originally observed in molluscan neurons (Connor and Stevens, 1971; Neher, 1971).

As shown below, a $\mathrm{Ca}^{2+}$-activated $\mathrm{K}^{+}$channel was also expressed by $M$. sexta ORNs. Because this channel was inactivated at a free internal $\mathrm{Ca}^{2+}$ concentration of $0.1 \mu \mathrm{M}$, a concentration also used for the whole-cell recordings, we believe that this type of channel did not contribute to the outward currents described here.

\section{Single-channel recordings}

The ionic currents were examined further at the single-channel level. We obtained stable recordings for up to $1 \mathrm{hr}$ in all 3 recording conditions (cell-attached, outside-out patch, and inside-out patch). During this time, none of the types of channels described here showed marked signs of "run down" (i.e., a timedependent loss of current). All patches were taken from the soma membrane of $M$. sexta ORNs.

\section{Delayed-rectifier $\mathrm{K}^{+}$channels}

In cell-attached recordings with extracellular saline in the pipette, no channel activity could be observed at the resting potential of the cell. The predominant type of channel observed in ORNs was a voltage-activated, noninactivating $\mathrm{K}^{+}$channel. Typical recordings of this type of channel elicited by stationary depolarization of the membrane patch are shown in Figure 3A. Small and short channel openings appear at $-35 \mathrm{mV}$ and become larger and more frequent with stronger depolarization. In this and other cell-attached patches, the membrane potential is equal to the difference between the cell potential and the pipette potential. We determined the cell potential using the whole-cell technique in the current-clamp mode after a cell-attached recording had been completed.

Figure $3 B$ gives the $I-V$ relationship of the channel openings presented in Figure $3 A$. Each point on the curve represents at least 200 single-channel current amplitudes, which were evaluated and plotted in amplitude histograms (as shown in Fig. 
Figure 5. Openings of the delayedrectifier $\mathrm{K}^{+}$channel evoked by voltage steps $(300 \mathrm{msec})$ from a holding potential of $-70 \mathrm{mV}$ to $0,+10$, and +25 $m V$. A cell-attached patch with extracellular solution in the pipette was used. Leak currents were digitally subtracted. In the lower traces, single-channel records obtained at the indicated potentials are summed, and the average currents are calculated to reconstruct the macroscopic currents.
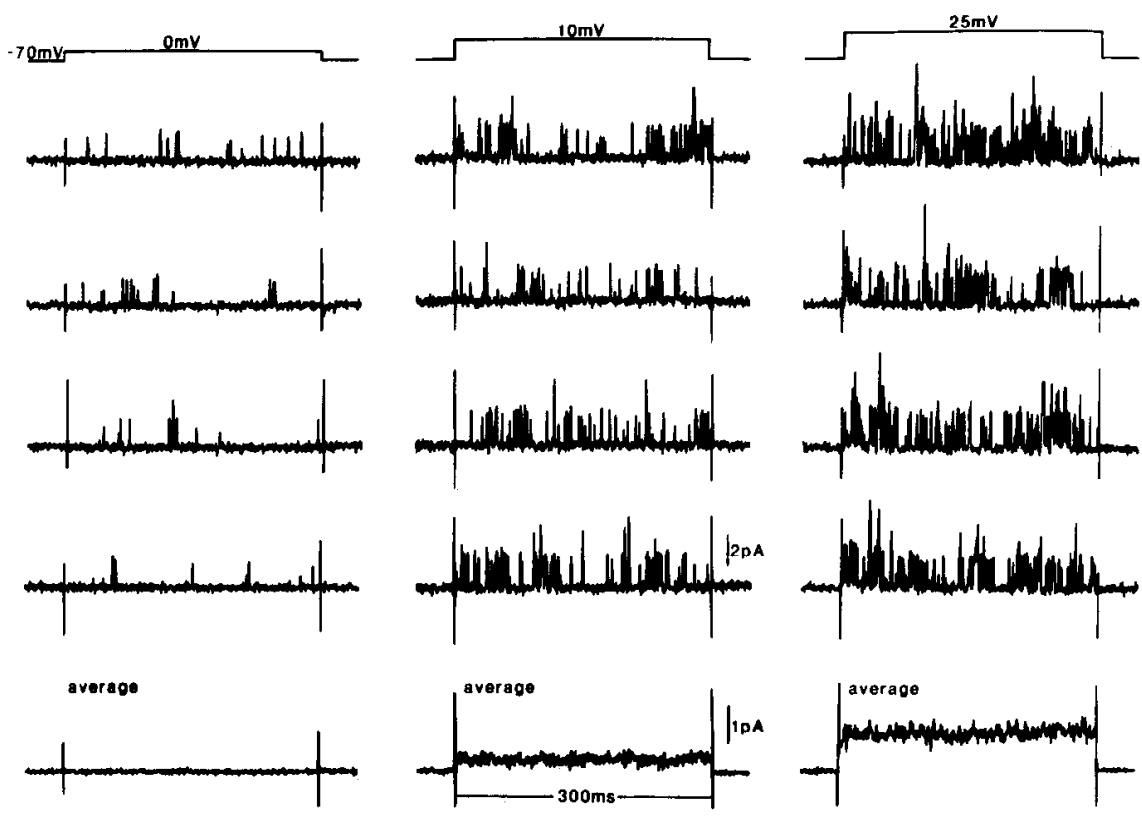

$10 A$ ). Between -35 and $+55 \mathrm{mV}$, the $I-V$ curve is linear. The calculated unitary conductance $\gamma$ is $30 \mathrm{pS}$. A clear reversal potential could not be determined because the single-channel currents did not reverse upon hyperpolarization up to $-150 \mathrm{mV}$ and thus showed outward rectification under the ionic conditions employed. Linear extrapolation of the $I-V$ curve results in a 0 -current potential of $-60 \mathrm{mV}$.

The open- and closed-time distributions for the $30-\mathrm{pS} \mathrm{K}^{+}$ channel (same patch as in Fig. 3) were evaluated in time histograms, as shown for 2 different membrane potentials in Figure 4. At $0 \mathrm{mV}$, the open-time distribution can be fit by a single exponential with a time constant $\tau$ of $0.5 \mathrm{msec}$ (Fig. $4 A$ ). This time constant represents the mean open time of single-channel openings. This value was constant among different patches and cells $(\tau=0.49 \pm 0.04 \mathrm{msec} ; n=11)$. The open-time distributions at $45 \mathrm{mV}$ can also be fit by a single exponential. The time constant is longer ( $0.85 \mathrm{msec}$; Fig. $4 B$ ), however: The distribution of closed times at $0 \mathrm{mV}$ can be fit by the sum of 2 exponentials with time constants of $\tau_{1}=1.4 \mathrm{msec}$ and $\tau_{2}=44.8$ msec (Fig. $4 D$ ). Depolarization to $45 \mathrm{mV}$ does not change the short time constant $\left(\tau_{1}=1.1 \mathrm{msec}\right)$ but reduces the long time constant $\tau_{2}$ to $3.2 \mathrm{msec}$ (Fig. $4 E$ ). The short time constants represent the short closings separating individual channel openings within a burst. Closed times between the bursts are represented by the longer time constants. Figure $4 C$ shows a linear correlation between channel open times and membrane potential for the $30-\mathrm{pS} \mathrm{K} \mathrm{K}^{+}$channel. Upon depolarization, the mean open time increased by $0.067 \mathrm{msec} / 10 \mathrm{mV}$. Unlike the mean open time, the probability of opening of the $30-\mathrm{pS} \mathrm{K} \mathrm{K}^{+}$channel was exponentially correlated with the membrane potential (Fig. $4 F$ ). The probability of channel opening increased from 0.025 at $-15 \mathrm{mV}$ to 0.67 at $55 \mathrm{mV}$. Thus depolarization incrcased both the probability and the duration of openings of the 30-pS $\mathrm{K}^{+}$channel $(n=15)$.

In the inside-out configuration, the 30-pS channel had characteristics (single-channel kinetics, $I-V$ relationship) identical to those observed in the cell-attached mode. If $\mathrm{K}^{+}$was replaced with $\mathrm{Cs}^{+}$in the "intracellular" solution, the single-channel cur- rent amplitude reversibly declined to 0 , suggesting that this type of channel is not permeable to $\mathrm{Cs}^{+}$. This finding might explain the loss of outward current in the whole-cell recording of Figure $2 B$.

$\mathrm{Ca}^{2+}$ and $\mathrm{Mg}^{2+}$ between $0.1 \mu \mathrm{M}$ and $1 \mathrm{~mm}$ both from the outside and the inside of the membrane had no effects on kinetics or open probability of the $30-\mathrm{pS} \mathrm{K} \mathrm{K}^{+}$channel (not shown).

In cell-attached recordings with high $\mathrm{K}^{+}$in the pipette, the 30-pS K+ channel lost its rectification (data not shown). Under nearly symmetrical $\mathrm{K}^{+}$concentrations, the $I-V$ curve became linear with a reversal potential near $0 \mathrm{mV}$. The single-channel conductance increased to $50 \mathrm{pS}$. The open probability at rest was low, with 0.001 at $-70 \mathrm{mV}(n=4)$, but it increased upon depolarization in a manner similar to that shown in Figure $4 F$. From these measurements, an intracellular $\mathrm{K}^{+}$concentration ncar $150 \mathrm{~mm}$ could be calculated for these ORNs.

To reconstruct the macroscopic current, the $30-\mathrm{pS} \mathrm{K}+$ channel was activated by depolarizing voltage steps (upper traces in Fig. 5). The macroscopic current was reconstructed by averaging at least 50 traces as shown in the lower traces of Figure 5. With larger depolarizations, the open probability of the channel increased. The latency to the first opening decreased with increasing voltages. The averaged single-channel currents reconstruct a sustained outward current similar to the sustained outward current component of the whole-cell recordings.

\section{Delayed-rectifier $K^{+}$channels can be modulated by nucleotides}

Upon application of nucleotides to the cytoplasmic face of inside-out patches, inhibition of the activity of the delayedrectifier $\mathrm{K}^{+}$channel was seen (Fig. 6). As shown in Figure $6 \mathrm{~A}$ (control), superpositions of up to 3 single-channel openings, as indicated by the different current levels, were present (holding potential $5 \mathrm{mV}$ ). Millimolar concentrations of ATP, cGMP, or cAMP added to the intracellular solution were applied to the patch each for about 2 min. During this time, the activity of the $30-\mathrm{pS} \mathrm{K}^{+}$channel was strongly reduced by ATP and cGMP (Fig. 6B,C) and to a smaller degree by cAMP (Fig. 6D). Between the drug applications and at the end of the experiment, activity 
A

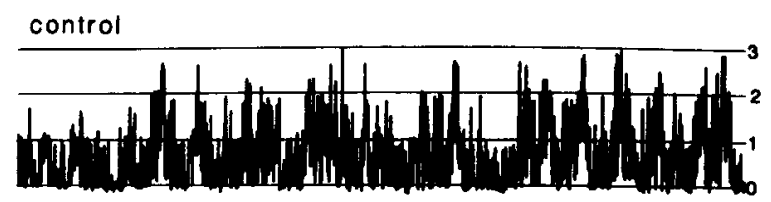

B

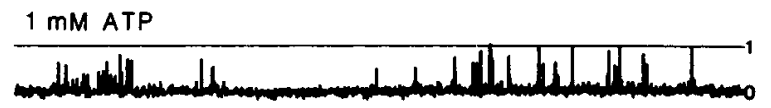

C

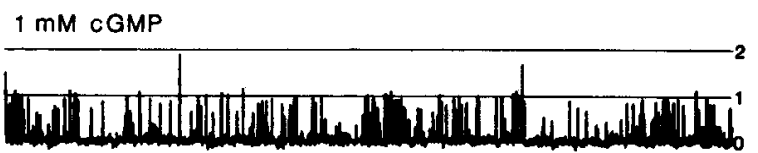

D

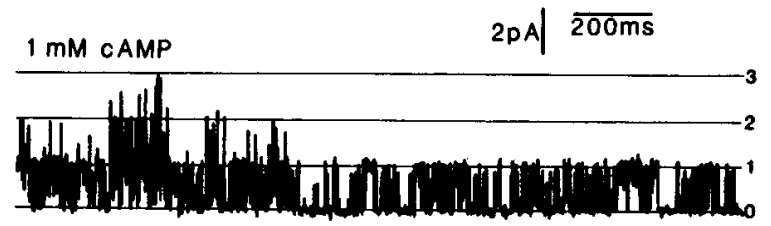

Figure 6. Effect of nucleotides on the activity of the delayed-rectifier $\mathrm{K}^{+}$channel: inside-out patch at a holding potential of $5 \mathrm{mV}$. $A$, Steadystate activity of $\mathrm{K}^{+}$channel openings. Superpositions of up to 3 singlechannel openings indicated by the different current levels can be seen. $B, C$, and $D$, Addition of millimolar concentration of $A T P, C G M P$, or cAMP to the "intracellular" solution reduced the activity of the delayedrectifier $\mathrm{K}^{+}$channcl. Control responses between the drug applications are not shown.

of the $30-\mathrm{pS} \mathrm{K}^{+}$channel was fully restored upon switching to the control solution (not shown). Quantification of the inhibitory effects of the nucleotides over a longer period of time is shown in Figure $7 A-D$ (same experiment as that in Fig. 6). For a steadystate drug application of $40 \mathrm{sec}$, the number of open channels per bin, which fluctuated during the measurements, could be calculated. Bin width is $0.5 \mathrm{sec}$. Mean values of open channels (indicated by the dottcd lines) were computed and normalized to the control. The resulting values are $13 \%$ of the control for ATP, $22 \%$ for cGMP, and $66 \%$ for cAMP (each at $10^{-3} \mathrm{M}$ ).

The dose-response relationship for the inhibitory effect of ATP is shown in Figure 7E. Mean current is plotted against ATP concentration. The curve connecting the current values is a least-squares fit of the data to the equation $y=100 /[1+(x)$ $\left.K_{I}\right)^{b}$ ], where $K_{I}=0.18 \mathrm{~mm}$ (the inhibition constant or halfmaximal inhibitory concentration of ATP) and $b=0.97$ (the Hill coefficient), suggesting a 1:1 binding of ATP.

The mean open time of single-channel currents in the presence of $1 \mathrm{~mm}$ ATP (at $5 \mathrm{mV})$ is delivered as $48 \pm 0.06 \mathrm{msec}(n=$ 5 ), which is nearly the same value as in control patches (see above). These results favor the idea that ATP exerts a direct effect on gating of the $30-\mathrm{pS} \mathrm{K}^{+}$channel, possibly via a specific binding site, and thus reduces the frequency of openings, rather than blocking the ionic pore.

To search for direct gating of nucleotides, as described for vertebrate olfactory neurons (Nakamura and Gold, 1987), inside-out patches $(n=18)$ were held at $-60 \mathrm{mV}$ and exposed at their cytoplasmic surface to cGMP and cAMP (added at a concentration of $0.1 \mathrm{mM}$ to divalent-cation-free intracellular solution in which $\mathrm{Mg}^{2+}$ had been omitted and $100 \mu \mathrm{M}$ EDTA added).
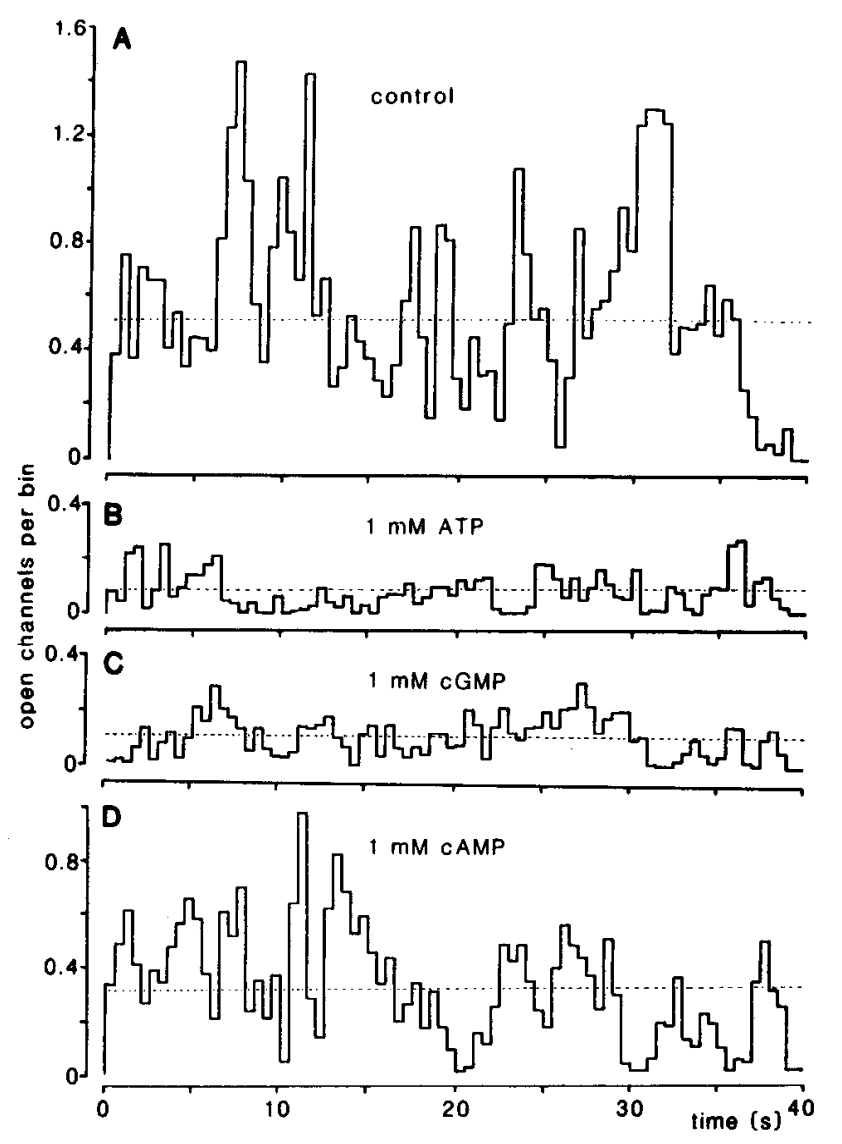

$\mathbf{E}$

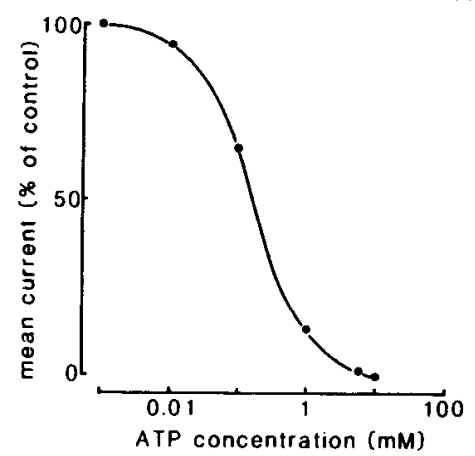

Figure 7. $A-D$, Plot of open channels per bin versus time for the inhibitory effects during continuous application of nucleotides on the activity of the delayed-rectifier $\mathrm{K}^{+}$channel (same patch as in Fig. 6). Bin width was $0.5 \mathrm{sec}$. Mean values of open channels (as indicated by the dotted lines) were $13 \%$ of the control for $A T P, 22 \%$ for $c G M P$, and $66 \%$ for $c A M P$ (each at $1 \mathrm{mM}$ ). $E$, Dose-response curve for the inhibitory effect of ATP on the activity of the delayed-rectifier $\mathrm{K}^{+}$channel. Mean current was normalized to the control and plotted against ATP concentration. The curve connecting the current values is a least-squares fit of the data to the equation $y=100 /\left[1+\left(x / K_{I}\right)^{b}\right]$, with $K_{I}=0.18 \mathrm{mM}$ and $b=0.97$.

Neither single-channel activity nor an increase in noise was observed.

\section{$\mathrm{Ca}^{2+}$-activated $\mathrm{K}^{+}$channels}

Another type of $\mathrm{K}^{+}$channel expressed by $M$. sexta ORNs in vitro is a $\mathrm{Ca}^{2+}$-activated $\mathrm{K}^{+}$channel. This channel type was never detected in cell-attached recordings, suggesting that the intracellular concentration of free $\mathrm{Ca}^{2+}$ in these cells was $\leq 0.1 \mu \mathrm{M}$ (see Fig. 8B). Only the $30-\mathrm{pS} \mathrm{K}^{+}$channel opened when an insideout patch (at a holding potential of $5 \mathrm{mV}$ ) was exposed to "nor- 

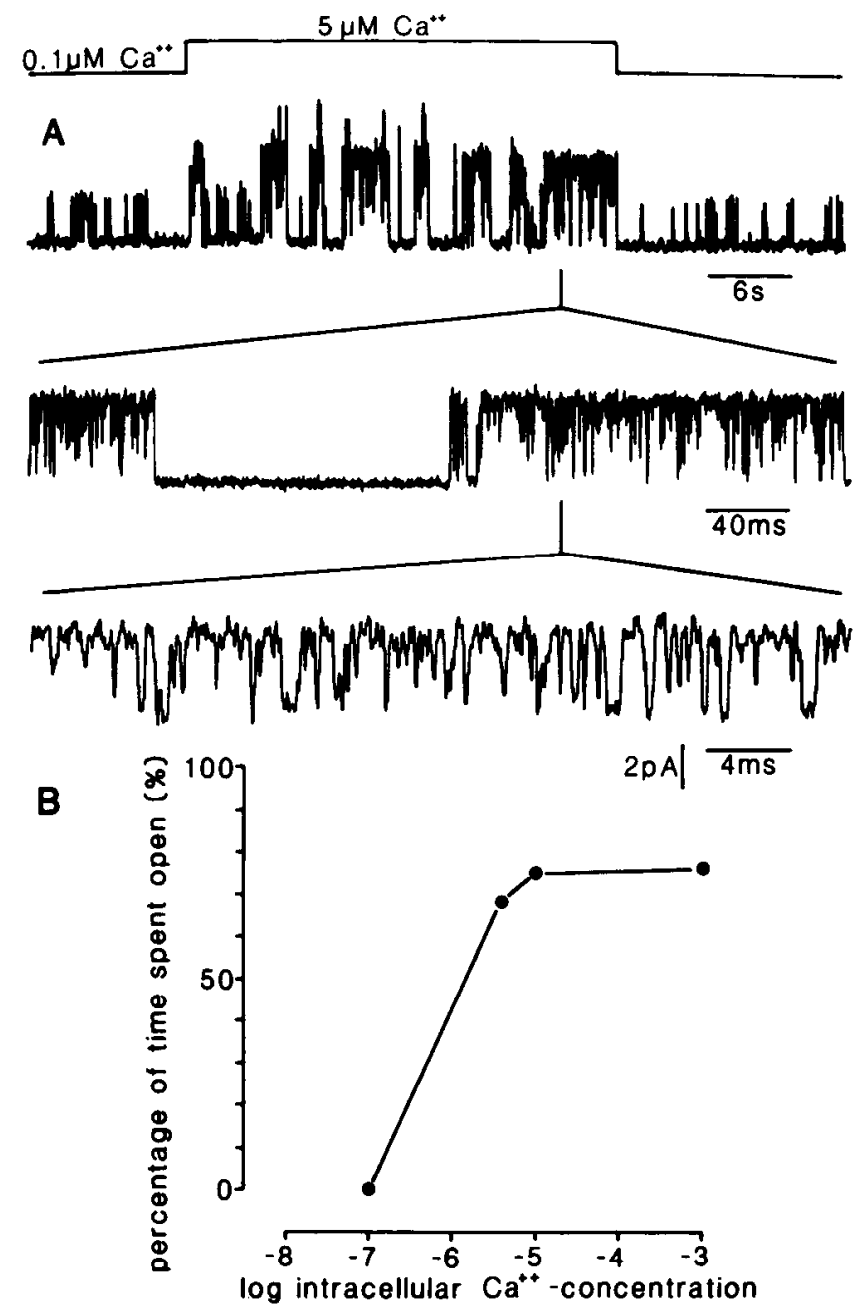

Figure 8. A, Activity of the $\mathrm{Ca}^{2+}$-activated $\mathrm{K}^{+}$channel in an insideout patch (at a holding potential of $5 \mathrm{mV}$, with asymmetrical $\mathrm{K}^{+}$solutions). Upper trace, With $0.1 \mu \mathrm{M}$ free $\mathrm{Ca}^{2+}$ in the intracellular solution, only openings of the delayed-rectifier $\mathrm{K}^{+}$channel were present. Raising the intracellular free $\mathrm{Ca}^{2+}$ concentration to $5 \mu \mathrm{M}$ induced the opening of a second, larger $\mathrm{K}^{+}$channel. Bandwidth of recording, $0-2 \mathrm{kHz}$. Middle and lower traces, A portion has been expanded to show long bursts and brief closures during openings. Bandwidth, $0-5 \mathrm{kHz} . \mathrm{B}, \mathrm{Ca}^{2+}$ sensitivity of the $\mathrm{Ca}^{2+}$-activated $\mathrm{K}^{+}$channel (same patch as in $A$, also at $5 \mathrm{mV}$ ). Each point of the curve represents the fraction of time the channel spent in the open state (\%; sample time, $30 \mathrm{sec}$ ) at the indicated $\mathrm{Ca}^{2+}$ concentration. The line between the points was drawn by eye.

mal" intracellular solution (containing $<10^{-7} \mathrm{M} \mathrm{Ca}^{2+}$ ). Rapid switching (by means of the liquid-filament switch) to an intracellular solution containing $5 \mu \mathrm{M}$ free $\mathrm{Ca}^{2+}$ induced the opening of a second, larger channel. This effect was reversible. $\mathrm{Ca}^{2+}$ gated channel openings were no longer observed when $\mathrm{K}^{+}$in the internal solution was replaced by $\mathrm{Na}^{+}$or $\mathrm{Cs}^{+}$, indicating that this channel is selective for $\mathrm{K}^{+}$. The middle and lower traces of Figure $8 A$ show currents through the $\mathrm{Ca}^{2+}$-activated $\mathrm{K}^{+}$channel on expanded time scales. Openings (upward current steps), separated by brief periods of channel closing, are grouped into bursts separated by longer closed intervals. The steep $\mathrm{Ca}^{2+}$ dependence of the $\mathrm{Ca}^{2+}$-activated $\mathrm{K}^{+}$channel is shown in Figure $8 B$. The fraction of time the channel spent in the open state (at $5 \mathrm{mV}$ holding potential) is plotted against the intracellular $\mathrm{Ca}^{2+}$ concentration $\left(\mathrm{Ca}_{i}\right)$. At a $\mathrm{Ca}_{i}$ of $0.1 \mu \mathrm{M}$, channel activity was not detected. As the $\mathrm{Ca}_{i}$ was raised to $5 \mu \mathrm{M}$, the fraction of time the
A
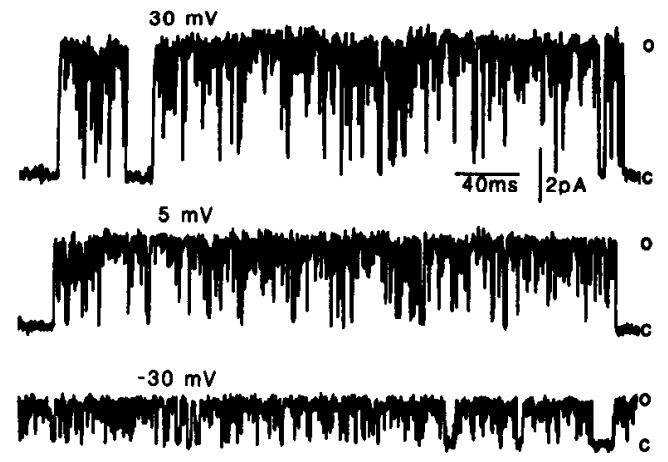

$-50 \mathrm{mV}$

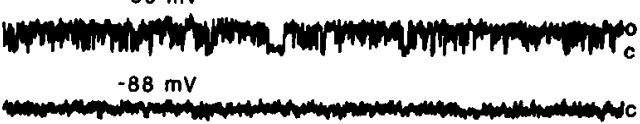

B

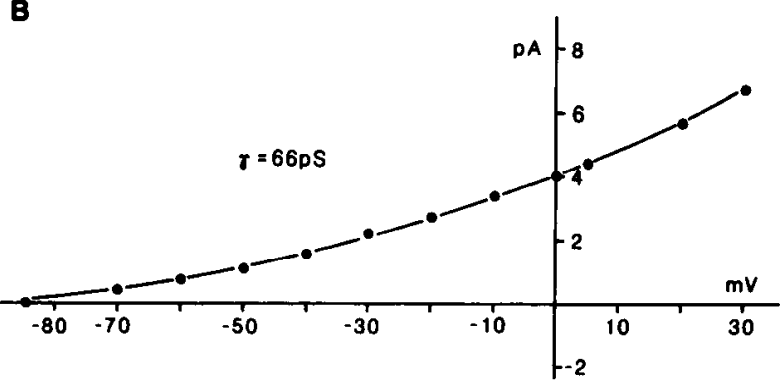

Figure 9. A, Steady-state activity of openings of the $\mathrm{Ca}^{2+}$-activated $\mathrm{K}^{+}$ channel at different holding potentials as indicated: same inside-out patch as in Figure 8 at a fixed intracellular $\mathrm{Ca}^{2+}$ concentration of $5 \mu \mathrm{M}$. Open $(o)$ and closed $(c)$ states of the channel are indicated at the right. $B$, The single-channel current-voltage relationship of the recordings shown in $A$. Each point of the curve represents at least 2000 singlechannel openings, which were evaluated and plotted in amplitude histograms as shown in Figure $10 \mathrm{~A}$. Zero-current potential was near -85 $\mathrm{mV}$; slope conductance (at $0 \mathrm{mV}$ ) was $\gamma=66 \mathrm{pS}$.

channel was open increased dramatically to $68 \%$ and reached a plateau of $75 \%$ at a $\mathrm{Ca}_{i}$ of $10 \mu \mathrm{M}$

The current-voltage relationship for the $\mathrm{Ca}^{2+}$-activated $\mathrm{K}^{+}$ channel at a fixed $\mathrm{Ca}_{i}$ of $5 \mu \mathrm{M}$ is presented in Figure 9. The $I-$ $V$ curve (Fig. $9 B$ ) reveals outward rectification when the $\mathrm{K}^{+}$ concentrations were asymmetric; the current direction could not be reversed with hyperpolarization up to $-150 \mathrm{mV}$. The 0 current potential was near $-85 \mathrm{mV}$, which is close to the Nernst potential for $\mathrm{K}^{+}(-87 \mathrm{mV})$. Because the $I-V$ relationship is not linear, the slope conductance was calculated at $0 \mathrm{mV}$ to be 66 pS. The $\mathrm{Ca}^{2+}$-activated $\mathrm{K}^{+}$channel showed little voltage dependence. Depolarization from $-50 \mathrm{mV}$ to $+30 \mathrm{mV}$ increased the fraction of time spent in the open state from $60 \%$ to $73 \%$ at a fixed $\mathrm{Ca}_{i}$ of $5 \mu \mathrm{M}$.

The distribution of amplitudes of single-channel openings (at a holding potential of $5 \mathrm{mV}$ ) is plotted in Figure $10 \mathrm{~A}$. Openings shorter than $500 \mu \mathrm{sec}$ were assumed to be incompletely resolved by our recording and analysis system and were therefore disregarded. In addition to the peak $I_{0}$, which represcnts thc closed state, a well-defined symmetrical peak $I_{1}$ (which gave no suggestion of the existence of substates) could be distinguished at $4.5 \mathrm{pA}$. The distribution of open times of the $\mathrm{Ca}^{2+}$-activated $\mathrm{K}^{+}$ channel could be fit by a single exponential ( $\tau=1.3 \mathrm{msec}$; Fig. $10 B)$. The mean open time shows little voltage dependence, varying between $0.95 \mathrm{msec}$ at $-50 \mathrm{mV}$ and $1.3 \mathrm{msec}$ at +30 
A
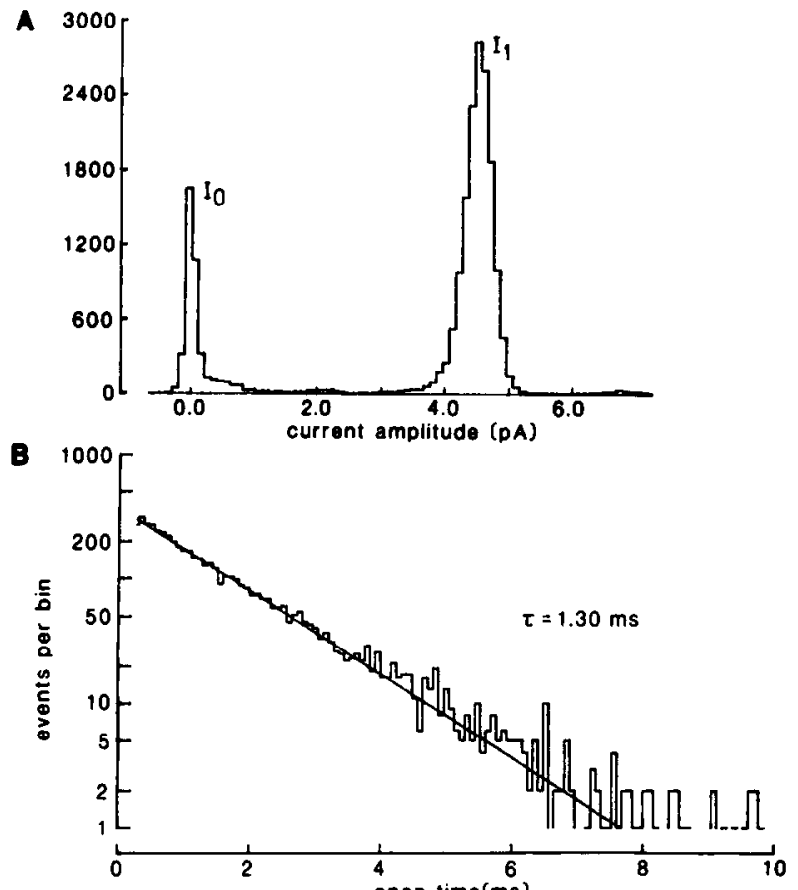

$\mathbf{C}$

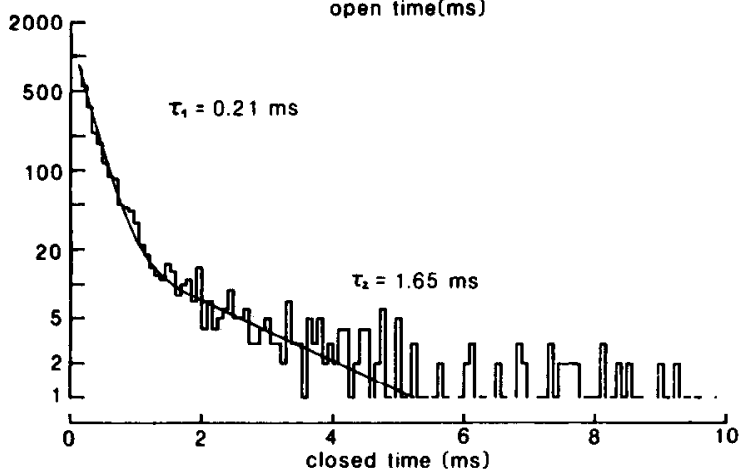

Figure 10. Evaluations of recordings from the inside-out patch shown in Figure 9. Membrane potential, $5 \mathrm{mV}$; intracellular free $\mathrm{Ca}^{2+}$ concentration, $5 \mu \mathrm{M}$. $A$, Distribution of amplitudes of single-channel openings longer than $500 \mu \mathrm{sec}$. Bin width, $0.1 \mathrm{pA}$. $I_{0}$ represented the closed state, and $I_{1}$, the open statc, of the channel. $B$, Distribution of channel open times. Bin width, $80 \mu \mathrm{sec}$. The distribution could be fit by a single exponential with a time constant of $\tau=1.3 \mathrm{msec}$. $C$. Distribution of closed times. The distribution was fit by 2 exponentials with time constants of $\tau_{1}=0.21 \mathrm{msec}$ and $\tau_{2}=1.65 \mathrm{msec}$, respectively. A longer time constant could not be fit to the data (see text).

$\mathrm{mV}$ (same patch as that in Fig. 10). The distribution of closed times could be fit by the sum of 2 exponentials, $\tau_{1}=0.21 \mathrm{msec}$ and $\tau_{2}=1.65 \mathrm{msec}$ (Fig. $10 \mathrm{C}$ ).

\section{Transient $K^{+}$channels}

A third, much smaller type of $\mathrm{K}^{+}$channel was found in only 4 patches, so that no detailed evaluation is shown here. In cellattached recordings with "normal" extracellular solution in the pipette, single-channel currents $(\gamma=12-18 \mathrm{pS})$ were activated by depolarizing steps from -90 to $+15 \mathrm{mV}$ (Fig. $11 \mathrm{~A}$ ). Leakage currents were subtracted. After the beginning of the voltage step, single-channel currents were activated within a few milliseconds. The prepulse inactivation curve is steep, and from a holding potential of $-50 \mathrm{mV}$, this type of channel could not be activated. Openings separated by brief closed intervals are grouped into bursts. Burst length differed between a few milli-

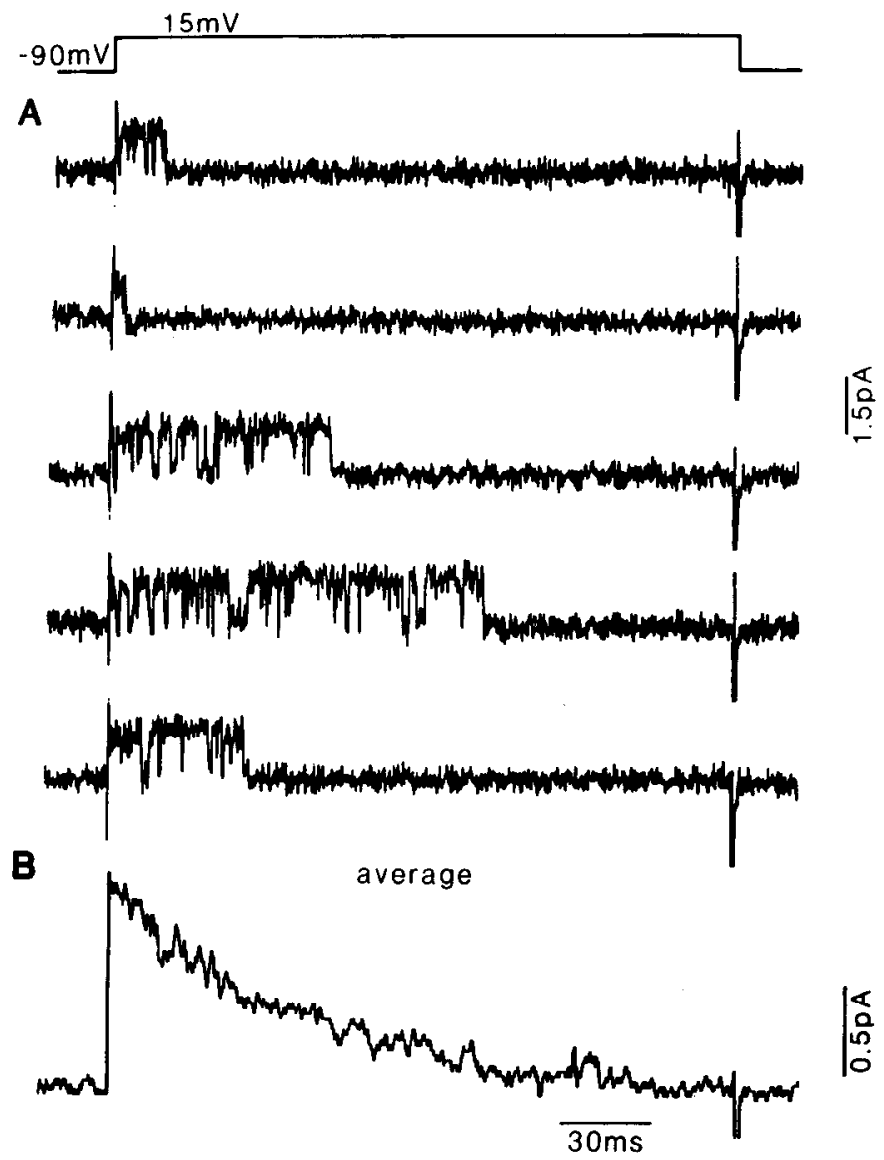

Figure 11. A, Openings of the transient $\mathrm{K}^{+}$channel evoked by voltage steps from -90 to $+15 \mathrm{mV}$ : cell-attached patch with extracellular solution in the pipette. Leak currents were digitally subtractcd. Bandwidth of recording, $0-2 \mathrm{kHz}$. $B$, Reconstruction of the macroscopic current Average current was obtained by the summation of 52 single-channel activations. Inactivation occurred with a time constant of about 70 msec.

seconds to about $100 \mathrm{msec}$. With maintained depolarization, the channel inactivated within $150 \mathrm{msec}$. Openings always occurred at the beginning of the pulse, but the rate of reopening differed from pulse to pulse. From the estimated 0 -current potential and the outward rectification, it appears that this type of channel was primarily permeable to $\mathrm{K}^{+}$.

To reconstruct the macroscopic current attributable to the transient $\mathrm{K}^{+}$channel, we averaged 52 traces such as those in Figure $11 \mathrm{~A}$ (Fig. $11 \mathrm{~B}$ ). The shape of the average current shows clear properties of activation and inactivation and bears close resemblance to the inactivating outward current component of the whole-cell records (Fig. $2 C, D$ ). Inactivation occurred in an exponential fashion with a time constant of about $70 \mathrm{msec}$. These recordings strongly suggest that activation of this small, transient $\mathrm{K}^{+}$channel is responsible for the inactivating component of the outward current shown in Figures 1 and 2.

\section{Sodium channels}

In a search for $\mathrm{Na}^{+}$channels, we used the same experimental protocol as for the activation of the transient $\mathrm{K}^{+}$channel. In cell-attached patches $(n=23)$ from the soma membrane of $M$. sexta ORNs, we did not observe voltage-activated inward currents. 


\section{Discussion}

We have presented electrophysiological evidence for the physiological differentiation of isolated ORNs dissociated from antennal flagella of male $M$. sexta pupae and maintained for at least 2 weeks in cell culture. These cells expressed at least 1 type of sodium channel and at least 3 types of potassium channels in vitro.

Membrane excitability and the underlying ionic currents in $M$. sexta ORNs in vitro were similar to those of freshly isolated vertebrate ORNs (Trotier, 1986; Firestein and Werblin, 1987; Maue and Dionne, 1987) and to insect motorneurons (Thomas, 1984). We found resting potentials of $-62 \pm 12 \mathrm{mV}$ in $M$. sexta ORNs. At less negative resting potentials (beyond $-50 \mathrm{mV}$ ), most of the $\mathrm{Na}^{+}$channels would probably be inactivated. The input resistance was high, with a mean value of $0.7 \mathrm{G} \Omega$, but lower (by a factor of 5-10) than that reported for vertebrate ORNs (Firestein and Werblin, 1987). The input resistance might be greater in situ, however, where supporting cells enwrap the ORN soma and are closely apposed to its membrane (Keil and Steinbrecht, 1987).

Under "normal" ionic conditions (i.e., with $\mathrm{Na}^{+}$as the main cation in the extracellular and $\mathrm{K}^{+}$the main cation in the intracellular solution), all outward currents in $M$. sexta ORNs were carried by $\mathrm{K}^{+}$, and all inward currents, by $\mathrm{Na}^{+}$. There was no evidence for the existence of any conductance open at the resting potential or of inward rectifying channels, which are typical, for example, for some kinds of glial cells (Nilius and Reichenbach, 1988 ) and for trichogen cells of the moth's sensilla trichodea (F. Zufall, unpublished observations).

$\mathrm{Na}^{+}$currents in $M$. sexta ORNs were blocked by low concentrations of TTX. The voltage dependence of these $\mathrm{Na}^{+}$currents could not be fully characterized, however, because we were unable to achieve a good space clamp when studying them. Our inability to space clamp the $\mathrm{Na}^{+}$currents, together with the fact that no single-channel $\mathrm{Na}^{+}$currents could be recorded at the soma membrane, suggest that $\mathrm{Na}^{+}$channels are not located in the soma membrane of these ORNs. This finding is not surprising, because the somata of invertebrate neurons typically have been found to be electrically inexcitable, including cockroach motorneurons (Thomas, 1984), Musca neurons in primary cell culture (Sattelle et al., 1988), and Helix neurons (Daut, 1973). Spike initiation is assumed to occur in moth ORNs either in the dendrite (De Kramer, 1985) or in the axon near the soma (Kaissling, 1987).

$\mathrm{No} \mathrm{Ca}^{2+}$ currents were found in $M$. sexta ORNs (see Fig. $2 B$ ). This contrasts with the findings of Troticr (1986) and Firestein and Werblin (1987) in their studies of vertebrate ORNs. These investigators demonstrated small, sustained, voltage-dependent inward currents blocked by cobalt. The possibility that $\mathrm{Ca}^{2+}$ currents are present in $M$. sexta ORNs cannot be excluded, however. Thus, $\mathrm{Ca}^{2+}$ currents could be downregulated as has been shown for Aplysia bag-cell neurons, in which phorbol esters activate a previously silent form of $\mathrm{Ca}^{2+}$ channel (Strong et al., 1987), or they could occur at a very low density in the soma membrane and hence not be detected.

We observed at least 3 types of $\mathrm{K}^{+}$channels in $M$. sexta ORNs. The 30-pS $\mathrm{K}^{+}$channel activates with depolarization and resembles the delayed-rectifier $\mathrm{K}^{+}$channel described in a number of cells (mouse ORNs, Maue and Dionne, 1987; cockroach CNS neurons, Beadle and Lees, 1986; for review, see Rudy, 1988). The kinetic behavior of this type of channel is characteristic of a delayed-rectifier channel, including the decrease in the latency of opening, the increase in the probability of opening with increasing depolarization, the slow time course of inactivation with prolonged depolarization, and the voltage dependence of the distributions of the open and closed durations. What is unusual for a delayed-rectifier channel, however, is the inhibition by nucleotides exhibited by this $30-\mathrm{pS} \mathrm{K}^{+}$channel. The nucleotides have relative potencies of ATP $>$ cGMP $>$ cAMP. Heretofore, ATP-sensitive $\mathrm{K}^{+}$channels have been described in 3 types of tissues (for references, see Ashcroft, 1988): mammalian cardiac muscle, adult frog skeletal muscle, and mammalian pancreatic $\beta$-cells. In these tissues, the ATP-sensitive channels are assumed to link electrical excitability to the metabolic state of the cell. While all other reported ATP-sensitive $\mathrm{K}^{+}$channels show little voltage dependency or inward rectification, however, this is the first description of an ATP-sensitive delayed-rectifier $\mathrm{K}^{+}$channel. Basal ATP concentrations of $2-8 \mathrm{~mm}$ have been described in a number of cells (Lehninger, 1982). At this concentration of ATP, the activity of the $30-\mathrm{pS} \mathrm{K}^{+}$channel would be strongly inhibited (see Fig. $7 E$ ). The basal concentration of cGMP in whole moth antennae is approximately micromolar and can increase about 1.3 -fold in response to pheromone (Ziegelberger, 1990). In this concentration range, the $30-\mathrm{pS} \mathrm{K}^{+}$ channel would not be affected. Nevertheless, local concentrations of cGMP near the channels might be much higher than reported for the whole antenna and might change the availability of $30-\mathrm{pS} \mathrm{K} \mathrm{K}^{+}$channels during pheromonal stimulation.

In vertebrates, the recent discoveries of an odorant-stimulated adenylate cyclase in isolated olfactory cilia (Pace et al., 1985) and a cyclic-nucleotide-gated conductance from ciliary and soma membranes of toad ORNs (Nakamura and Gold, 1987) have suggested that cyclic nucleotides play an important role in vertebrate olfactory transduction (Firestein and Shepherd, 1989). In $M$. sexta ORNs, no cyclic-nucleotide-gated conductance has been found so far, however, suggesting that different olfactory transduction mechanisms may operate in insects. This idea is supported by biochemical findings that the activity of G-proteindependent phospholipase $\mathrm{C}$, and not of adenylate cyclase, increases in insect antennae in response to stimulation with odor (Raming et al., 1989; Breer et al., 1990).

The second type of potassium channel, a $\mathrm{Ca}^{2+}$-activated $\mathrm{K}^{+}$ channel, does not fit easily into the scheme of big-conductance (BK) and small-conductance (SK) $\mathrm{Ca}^{2+}$-activated $\mathrm{K}^{+}$channels from vertebrates (Blatz and Magleby, 1987; McManus and Magleby, 1988). Compared to BK channels with a conductance of $100-300 \mathrm{pS}$, the $\mathrm{Ca}^{2+}$-activated $\mathrm{K}^{+}$channel has a relatively small conductance of $66 \mathrm{pS}$ and is rather voltage insensitive. The $\mathrm{Ca}^{2+}$ activation curve is comparable to that of the $130-\mathrm{pS} \mathrm{K}^{+}$channel described in mouse ORNs (Maue and Dionne, 1987). $\mathrm{Ca}^{2+}$ activated $\mathrm{K}^{+}$channels play an important role in repetitive firing and afterhyperpolarization of some neurons (Hille, 1984) and might play a similar role in insect antennae.

The third type of $\mathrm{K}^{+}$channel closely resembles the "A-channel" recorded from Drosophila neurons (Solc et al., 1987) in its time course of voltage-dependent activation and inactivation and its well-defined bursting behavior. Its conductance (12-18 pS) is nearly twice that of the Drosophila A-channel (5-8 pS). Such A-channels are believed to play a role in encoding graded depolarizations into spike trains (Connor and Stevens, 1971). Another possible function for the A-channel, modulation of the excitatory neuronal input, has been described by Daut (1973). The comparably small number of patches found to contain the 
A-current suggest that this channel normally may be located mainly on the processes of the cell.

Description of the electrical properties and ion-channel composition of the membrane of the ORNs is a necessary prerequisite for studies of primary olfactory transduction mechanisms. Until now, this information was not available for insect ORNs because intracellular recordings from these sensory receptor cells have not been possible in situ. Possible roles for the channels described here in olfactory transduction mechanisms in $M$. sexta ORNs are being addressed in our current work.

\section{References}

Ashcroft FM (1988) Adenosine 5'-triphosphate-sensitive potassium channels. Annu Rev Neurosci 11:97-118.

Bcadlc DJ, Lecs G (1986) Insect ncuronal cultures-a new tool in insect neuropharmacology. In: Neuropharmacology and pesticide action (Ford MG, Lunt GG, Reay RC, Usherwood PNR, eds), pp 423444. Chichester: Ellis Horwood.

Bell RA, Joachim FA (1976) Techniques for rearing laboratory colonies of tobacco hornworms and pink bollworms. Ann Ent Soc Am 69:365-373.

Blatz AL, Magleby KL (1987) Calcium-activated potassium channels. Trends Neurosci 10:463-467.

Breer H, Boekhoff I, Tareilus E (1990) Rapid kinetics of second messenger formation in olfactory transduction. Nature 345:65-68.

Connor JA, Stevens CF (1971) Prediction of repetitive firing behaviour from voltage clamp data on an isolated neurone soma. J Physiol (Lond) 213:31-53.

Daut J (1973) Modulation of the excitatory synaptic responsc by fast transient $\mathrm{K}^{+}$current in snail neurones. Nature 246:193-196.

De Kramer JJ (1985) The electrical circuitry of an olfactory sensillum in Antheraea polyphemus. J Neurosci 5:2484-2493.

Dudel J, Franke C (1987) Single glutamate-gated synaptic channels at the crayfish neuromuscular junction. II. Dependence of channel open time on glutamate concentration. Pfluegers Arch 408:307-314.

Firestein S, Shepherd GM (1989) Olfactory tranduction is mediated by the direct action of cAMP. Soc Neurosci Abstr 15:749.

Firestein S, Werblin FS (1987) Gated currents in isolated olfactory receptor neurons of the larval tiger salamander. Proc Natl Acad Sci USA 84:6292-6296.

Franke C, Hatt $\mathrm{H}$ (1990) Characteristics of single $\mathrm{Na}^{+}$-channels on adult human skeletal muscle. Pfluegers Arch 415:399-406.

Franke C, Hatt H, Dudel J (1987) Liquid filament switch for ultrafast exchanges of solutions at excised patches of synaptic membrane of crayfish muscle. Neurosci Lett 77:199-204.

Hamill OP, Marty A, Neher E, Sakmann B, Sigworth FJ (1981) Improved patch-clamp techniques for high-resolution current recording from cells and cell-free membrane patches. Pfluegers Arch 391:85100.

Hille B (1984) Ionic channels of excitable membranes. Sunderland, MA: Sinauer.

Hishinuma A, Hockfield S, McKay R, Hildebrand JG (1988a) Monoclonal antibodies reveal cell-type-specific antigens in the sexually dimorphic olfactory system of Manduca sexta. I. Generation of monoclonal antibodies and partial characterization of the antigens. J Neurosci 8:296-307.

Hishinuma A, Hockficld S, McKay R, Hildcbrand JG (1988b) Monoclonal antibodies reveal cell-type-specific antigens in the sexually dimorphic olfactory system of Manduca sexta. II. Expression of antigens during postembryonic development. J Neurosci 8:308-315.

Kaissling K-E (1986) Chemo-electrical transduction in insect olfactory receptors. Annu Rev Neurosci 9:121-145.

Kaissling K-E (1987) R. H. Wright lectures on insect olfaction. Burnaby, Can: Simon Fraser University.

Kaissling K-E, Hildebrand JG, Tumlinson JH (1989) Pheromone receptor cells in the male moth Manduca sexta. Arch Insect Biochem Physiol 10:273-279.

Keil TA (1989) Fine structure of the pheromone-sensitive sensilla on the antenna of the hawkmoth, Manduca sexta. Tissue Cell 21:139_ 151.

Keil TA, Steinbrecht RA (1987) Diffusion barriers in silkmoth sensory cpithelia: application of lanthanum tracer to olfactory sensilla of $\mathrm{An}$ theraea polyphemus and Bombyx mori. Tissue Cell 19:119-134.

Lee J-K, Strausfeld NJ (1990) Structure, distribution, and number of surface sensilla and their receptor cells on the antennal flagellum of the male sphinx moth Manduca sexta. J Neurocytol 19:519-538.

Lehninger AL (1982) Principles of biochemistry. New York: Worth.

Maue RA, Dionne VE (1987) Patch-clamp studies of isolated mouse olfactory receptor neurons. J Gen Physiol 90:95-125.

McManus OB, Magleby KL (1988) Kinetic states and modes of single large-conductance calcium-activated potassium channels in cultured rat skeletal muscle. J Physiol (Lond) 402:79-120.

Nakamura T, Gold GH (1987) A cyclic nucleotide-gated conductance in olfactory receptor cilia. Nature 325:442-444.

Neher, E (1971) Two fast transient current components during voltage clamp on snail neurons. J Gen Physiol 58:36-53.

Nilius B, Reichenbach A (1988) Efficient $\mathrm{K}^{+}$buffering by mammalian retinal glial cells is due to cooperation of specialized ion channels. Pfluegers Arch 411:654-660.

Pace U, Hanski E, Salomon Y, Lancet D (1985) Odorant-sensitive adenylate cyclase may mediate olfactory reception. Nature 316:255258.

Quartararo N, Barry PH (1987) A simple technique for transferring excised patches of membrane to different solutions for single channel measurements. Pfluegers Arch 410:677-678.

Raming K, Boekhoff I, Strotmann J, Breer H (1989) Molecular elements of olfactory signal transduction in insect antennae. In: Dynamics and plasticity in neuronal systems (Elsner N, Singer W, eds), p. 74. Stuttgart: Thieme.

Rudy B (1988) Diversity and ubiquity of K channcls. Ncurosciencc 25:729-749.

Sanes JR, Hildebrand JG (1976a) Structure and development of antennae in a moth, Manduca sexta. Dev Biol 51:282-299.

Sanes JR, Hildebrand JG (1976b) Origin and morphogenesis of sensory neurons in an insect antenna. Dev Biol 51:300-319.

Sattelle DB, Leech CA, Lummis SCR, Harrison BJ, Robinson HPC, Moores GD, Devonshire AL (1988) Ion channel properties of insects susceptible and resistant to insecticides. In: Neurotox '88: molecular basis of drug and pesticide action (Lunt GG, ed), pp 563-582. Amsterdam: Elsevier.

Solc CK, Zagotta WN, Aldrich RW (1987) Single-channel and genetic analyses reveal two distinct A-type potassium channels in Drosophila. Science 236:1094-1098.

Stengl M, Hildebrand JG (1990) Insect olfactory neurons in vitro: morphological and immunocytochemical characterization of malespecific antennal receptor cells from developing antennae of male Manduca sexta. J Neurosci 10:837-847.

Stengl M, Zufall F, Hatt H, Dudel J, Hildebrand JG (1989) Patch clamp analysis of male Manduca sexta olfactory receptor neurons in primary cell culture. Soc Neurosci Abstr 15:751.

Strong JA, Fox AP, Tsien RW, Kaczmarek LK (1987) Stimulation of protein kinase C recruits covert calcium channels in Aplysia bag cell neurons. Nature 325:714-717.

Thomas MV (1984) Voltage-clamp analysis of calcium-mediated potassium conductance in cockroach (Periplaneta americana) central neurones. J Physiol (Lond) 350:159-178.

Tolbert LP, Matsumoto SG, Hildebrand JG (1983) Development of synapses in the antennal lobes of the moth Manduca sexta during metamorphosis. J Neurosci 3:1158-1175.

Trotier D (1986) A patch-clamp analysis of membrane currents in salamander olfactory receptor cells. Pfluegers Arch 407:589-595.

Ziegelberger G, van den Berg MJ, Kaissling K-E, Klumpp S, Schultz JE (1990) Cyclic GMP levels and guanylate-cyclase activity in pheromone sensitive antennae of the silkmoths Antheraea polyphemus and Bombyx mori. J Neurosci 10:1217-1225.

Zufall F, Stengl M, Hildebrand JG, Hatt H (1989) A patch clamp study of cultured olfactory receptor neurons from Manduca sexta. In: Dynamics and plasticity in neuronal systems (Elsner N, Singer W, eds), p 75. Stuttgart: Thieme. 